\title{
A MULTISPECTRAL SCANNER SURVEY OF THE ROCKY FLATS ENVIRONMENTAL TECHNOLOGY SITE AND SURROUNDING AREA
}

GOLDEN, COLORADO

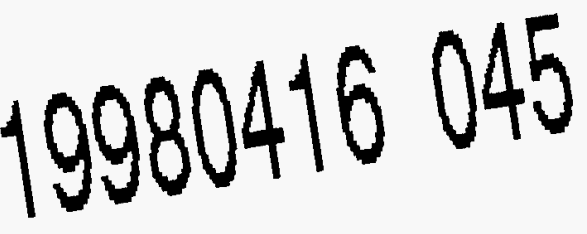

DETTIBUTION OF TIS DOCUMENT IS UNLIMTE 


\section{DISCLAIMER}

This report was prepared as an account of work sponsored by an agency of the United States government. Neither the United States government nor an agency thereof, or any of their employees, makes a warranty, express or implied, or assumes legal liability or responsibility for the accuracy, completeness, or usefulness of any disclosed information, apparatus, product, or process, or represents that its use would not infringe privately owned rights. Reference herein to a specific commercial product, process, or service by trade name, trademark, manufacturer, or otherwise does not necessarily constitute or imply an endorsement, recommendation, or favoring by the United States government or an agency thereof. The views and opinions of the authors expressed herein do not necessarily state or reflect those of the United States government or an agency thereof.

This report has been reproduced directly from the best available copy.

This report is available to DOE and DOE contractors from the Office of Scientific and Technical Information, P.O. Box 62, Oak Ridge, TN 37831. Call (423) 576-8401 to obtain prices.

This report is available to the public from the National Technical Information Service, U.S. Department of Commerce, 5285 Port Royal, Springfield, VA 22161. Call (703) 487-4650 for information. 


\title{
A MULTISPECTRAL SCANNER SURVEY OF THE ROCKY FLATS ENVIRONMENTAL TECHNOLOGY SITE AND SURROUNDING AREA
}

\author{
GOLDEN, COLORADO
}

DATE OF SURVEY: JUNE 1994

\author{
S.B. Brewster, Jr. \\ D.W. Brickey \\ S.L. Ross \\ J.E. Shines
}

Project Scientists

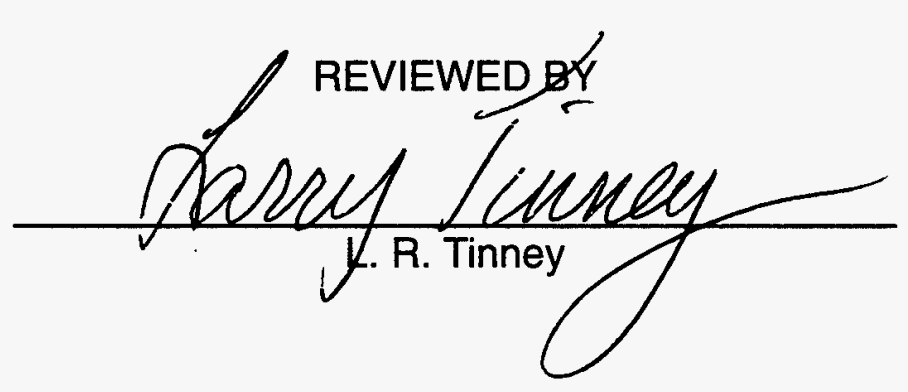

This Document is UNCLASSIFIED

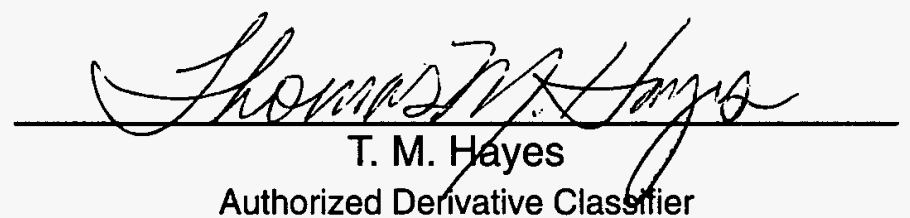

This work was performed for the U.S. Department of Energy by EG\&G/EM under Contract Number DE-AC08-93NV11265 and Bechtel Nevada under Contract Number DE-AC08-96NV11718. 


\section{ABSTRACT}

Aerial multispectral scanner imagery was collected of the Rocky Flats Environmental Technology Site in Golden, Colorado, on June 3, 5, 6, and 7, 1994, using a Daedalus AADS1268 multispectral scanner and coincident aerial color and color infrared photography. Flight altitudes were 4500 feet (1372 meters) above ground level to match prior 1989 survey data; 2000 feet (609 meters) above ground level for sitewide vegetation mapping; and 1000 feet (304 meters) above ground level for selected areas of special interest.

A multispectral survey was initiated to improve the existing vegetation classification map, to identify seeps and springs, and to generate ARC/INFO Geographic Information System-compatible coverages of the vegetation and wetlands for the entire site including the buffer zone.

The multispectral scanner imagery and coincident aerial photography were analyzed for the detection, identification, and mapping of vegetation and wetlands. The multispectral scanner data were processed digitally while the color and color infrared photography were manually photointerpreted to define vegetation and wetlands. Several standard image-enhancement techniques were applied to the multispectral scanner data to assist image interpretation. A seep enhancement was applied and a color composite consisting of multispectral scanner channels 11,7 , and 5 (thermal infrared, mid-infrared, and red bands, respectively) proved most useful for detecting seeps, seep zones, and springs. The predawn thermal infrared data were also useful in identifying and locating seeps. The remote sensing data, mapped wetlands, and ancillary Geographic Information System-compatible data sets were spatially analyzed for seeps.

Multispectral scanner data and aerial photography were collected and analyzed, and the appropriate data sets were created. From these data sets, thematic maps for vegetation and seep potential were created. The data sets have been prepared for further analysis if the need arises. All required hard-copy and digital data have been provided to site personnel. 


\section{PROJECT PERSONNEL}

J.E. Shines ................. Mission Manager

G.E. Menkel ................ Multispectral Scanner Technician

V.A. Young $\ldots \ldots \ldots \ldots \ldots \ldots$ Multispectral Scanner Technician

J.M. Roed .................. Photo Technician

G.M. Butler ................. Pilot, Mission Coordinator

D.L. Horton ................. Pilot

E.R. McKinney ................ Aircraft Mechanic

S.B. Brewster, Jr. ............. Scientist (Lead Analyst)

D.W. Brickey ................ Scientist

S.L. Ross ................. Scientist

Special thanks are noted to Jody Nelson from Rocky Mountain Remediation Services for his assistance in identifying and delineating specific types of vegetation. 


\section{CONTENTS}

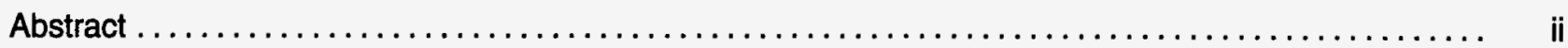

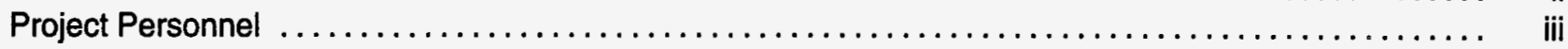

\section{Sections}

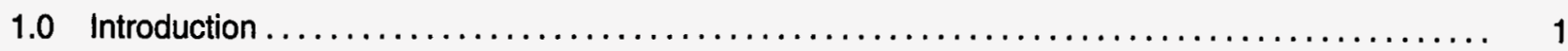

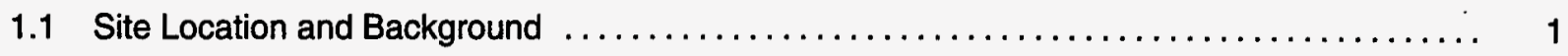

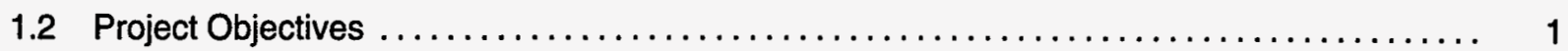

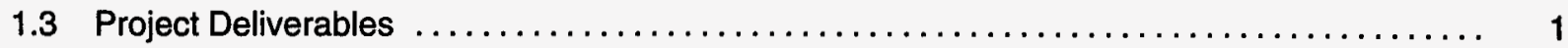

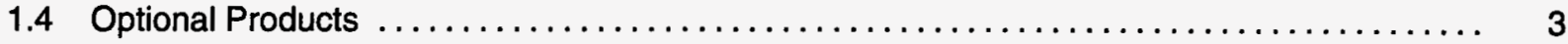

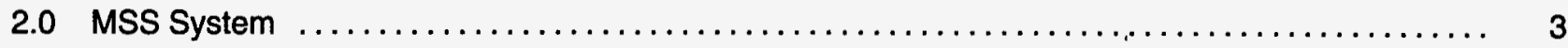

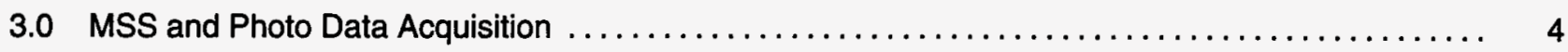

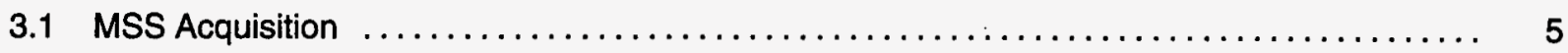

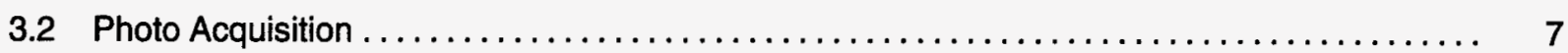

3.3 Flight-Line Summary $\ldots \ldots \ldots \ldots \ldots \ldots \ldots \ldots \ldots \ldots \ldots \ldots \ldots \ldots \ldots \ldots \ldots \ldots \ldots$

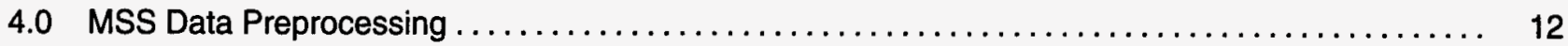

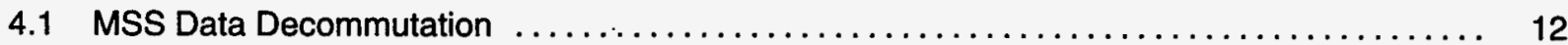

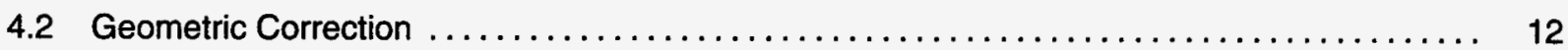

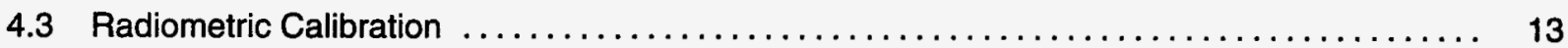

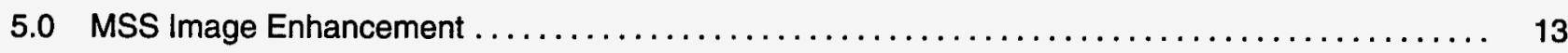

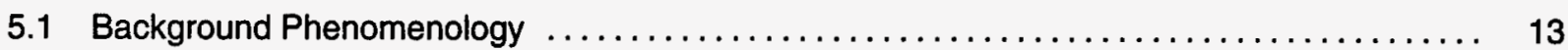

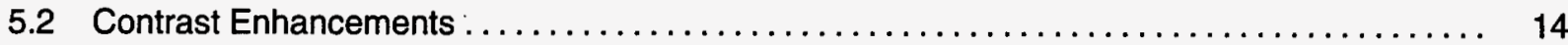

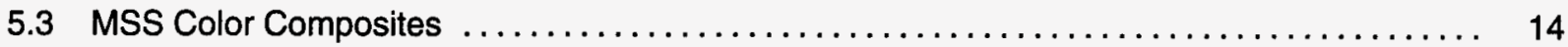

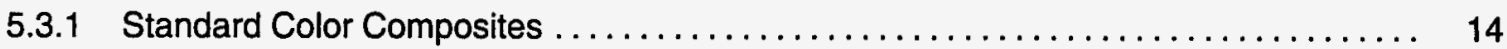

5.3.2 Vegetation Enhancement - Normalized Difference Vegetation Index .......... 16

5.3.3 Vegetation Enhancement - Kauth/Thomas Transformation .............. 16

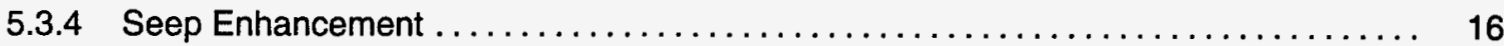

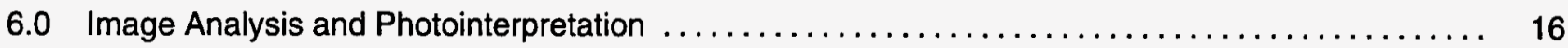

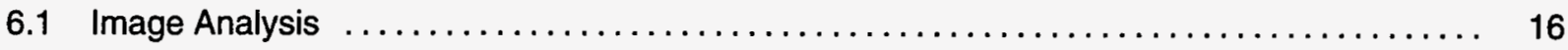

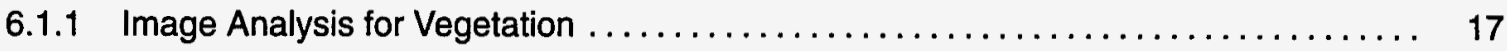

6.1.2 Image Analysis for Seeps and Wetlands $\ldots \ldots \ldots \ldots \ldots \ldots \ldots \ldots \ldots \ldots \ldots \ldots \ldots$

6.2 Photointerpretation for Vegetation and Wetlands $\ldots \ldots \ldots \ldots \ldots \ldots \ldots \ldots \ldots \ldots \ldots \ldots$ 
7.0 Data Automation, Data Analysis, and Map Production $\ldots \ldots \ldots \ldots \ldots \ldots \ldots \ldots \ldots \ldots \ldots \ldots$

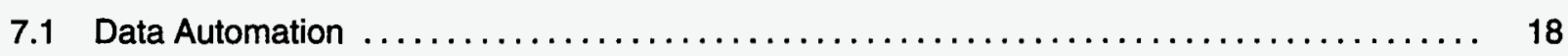

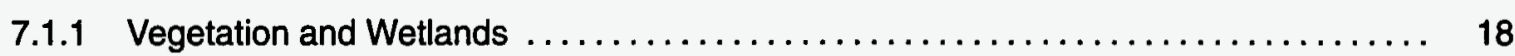

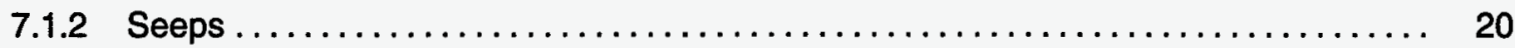

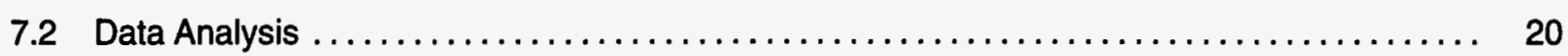

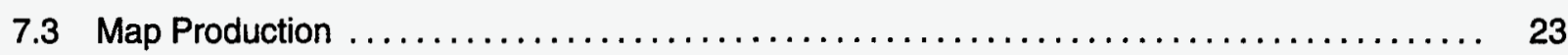

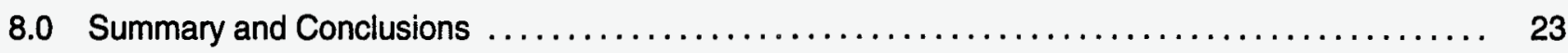

\section{Figures}

1 Rocky Flats Environmental Technology Site Orthophoto Image Map $\ldots \ldots \ldots \ldots \ldots \ldots \ldots \ldots$

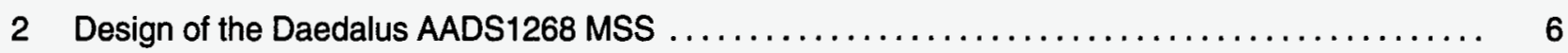

3 Rocky Flats Environmental Technology Site 4.5K Daytime MSS/Photo Coverage ........... 8

4 Rocky Flats Environmental Technology Site 2K Daytime MSS/Photo Coverage ........... 9

5 Rocky Flats Environmental Technology Site 1K Daytime and

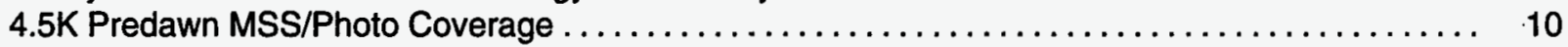

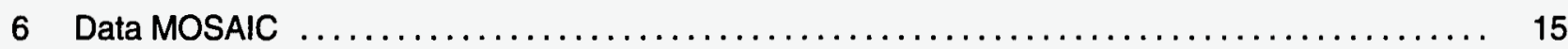

7 Vegetation Map of the Rocky Flats Environmental Technology Site $\ldots \ldots \ldots \ldots \ldots \ldots \ldots \ldots \ldots$

8 Seep-Potential Map of the Rocky Flats Environmental Technology Site . . . . . . . . . . . . . 22

\section{Tables}

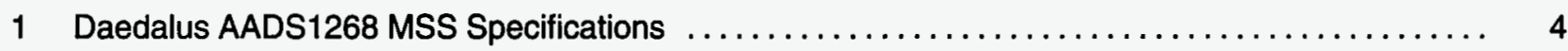

2 Measured Spectral Sensitivity of Daedalus AADS1268 MSS System $\ldots \ldots \ldots \ldots \ldots \ldots \ldots \ldots$

3 Multispectral and Photo Summary - Rocky Flats - June $1994 \ldots \ldots \ldots \ldots \ldots \ldots \ldots \ldots \ldots \ldots$

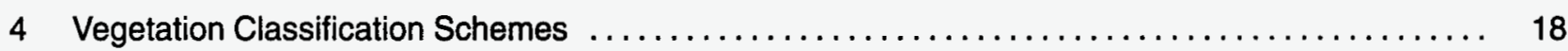

5 Correlation Between Vegetation Classification Scheme and U.S. Army Corps of Engineers' Wetlands Code $\ldots \ldots \ldots \ldots \ldots \ldots \ldots \ldots \ldots \ldots \ldots \ldots \ldots \ldots$

References 


\subsection{INTRODUCTION}

An aerial multispectral scanner (MSS) survey was conducted for the Rocky Flats Environmental Technology Site (RFETS) during early June 1994 . The survey was conducted by the Remote Sensing Laboratory (RSL) for the U.S. Department of Energy (DOE).

\subsection{Site Location and Background}

The RFETS (see Figure 1) is centered on approximately 6550 acres (2651 hectares) midway between the cities of Golden and Boulder, Colorado. ${ }^{1}$ The facility produced components for nuclear weapons and has been in operation since 1952. The site is located in a rural area characterized by mixed-grass prairie vegetation. It is bordered by the Rocky Mountains on the west and has an approximate elevation of 1 mile (1.6 kilometers) above mean sea level. It receives an average of 15 inches ( 38 centimeters) of precipitation per year. The area is drained by several ephemeral streams including the North Walnut Creek, South Walnut Creek, Rock Creek, and Woman Creek. Effluents generated on the site are processed and discharged through several series of ponds on the eastern side of the site.

The multispectral survey was initiated to improve the existing vegetation classification map, to identify seeps and springs, and to generate Geographic Information System (GIS) mapping products (ARC/INFO format) of the vegetation, wetlands, and potential seeps for the entire site including the buffer zone.

\subsection{Project Objectives}

The primary objectives of this project are specified below:

A. To acquire daytime 12-channel MSS data and coincident color aerial photography of the RFETS and surrounding buffer zone from an altitude of 4500 feet (1372 meters) above ground level (AGL).

B. To acquire daytime 12-channel MSS data and color aerial photography of the RFETS and surrounding buffer zone from an altitude of 2000 feet (609 meters) AGL.

C. To acquire daytime 12-channel MSS data and color infrared (CIR) aerial photography at five selected sites of the RFETS from an altitude of 1000 feet (304 meters) AGL. These sites included Woman Creek, Rock Creek drainage area, the landfill site, Ponds A1-A4, and Ponds B1 and B2.

D. To acquire predawn, thermal infrared (TIR) data of the RFETS and surrounding buffer zone from an altitude of 4500 feet (1372 meters) AGL.

E. To analyze these data and provide two maps in hard-copy and digital form: one map for vegetation classification and one for hydrology with emphasis on groundwater seeps and springs.

\subsection{Project Deliverables}

Project deliverables for this MSS and photographic survey included the following:

A. Six proof sets of color and CIR aerial photographs.

B. Six proof sets of the daytime 4500-foot (1372-meter) MSS data for the entire site and buffer zone that were seep enhanced.

C. Six proof sets of the daytime 1000-foot (304-meter) MSS data for the five selected sites that were seep enhanced. 


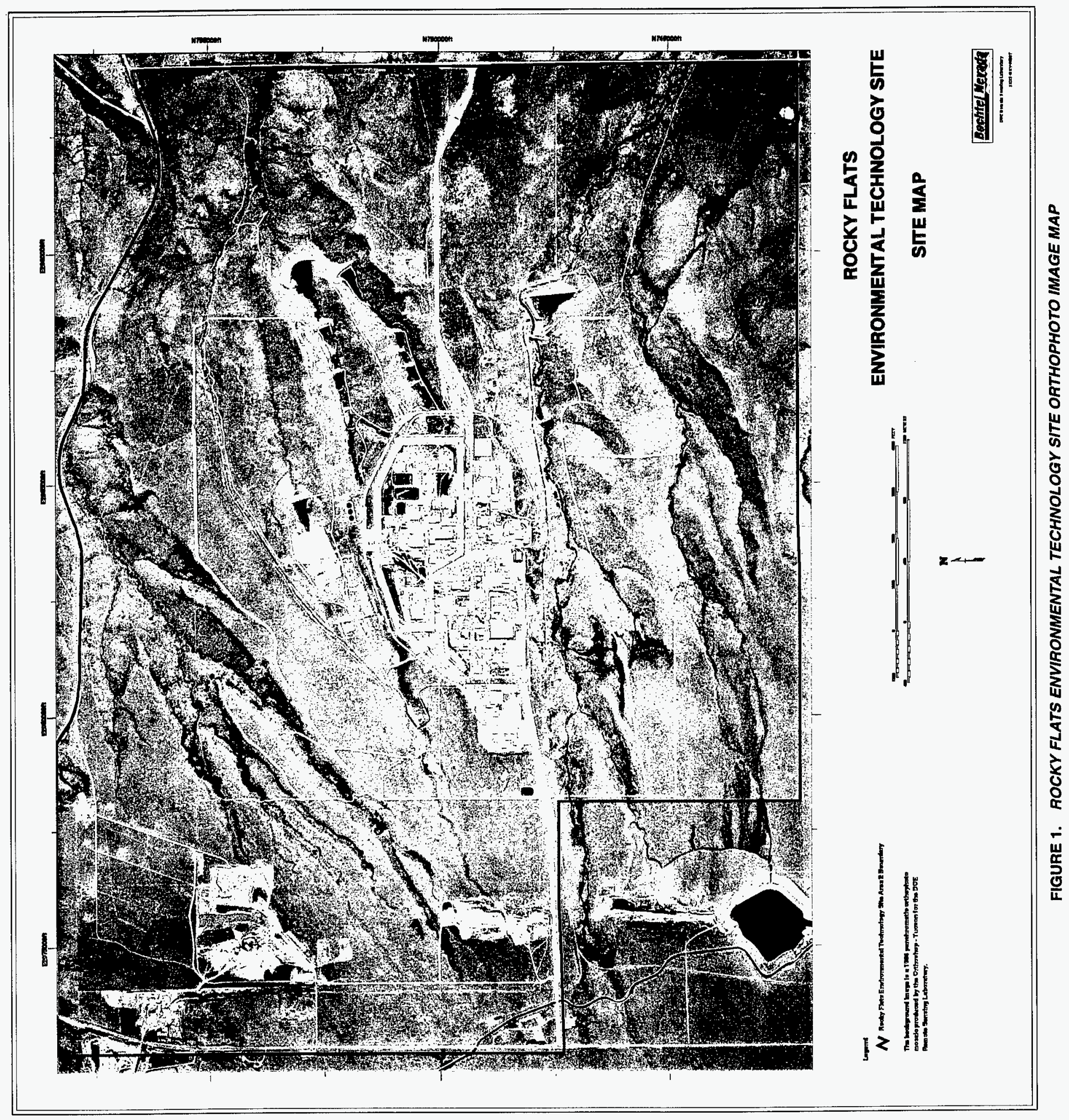


D. One copy of the aerial color VHS tape acquired during the survey.

E. One copy of MSS and photo flight logs.

F. Hard-copy and digital output of the interpreted hydrology and vegetation classifications with the format of the digital data readable by ARC/INFO.

G. Mission summary report.

Items A through $E$ were provided to RFETS personnel within 60 days following the conclusion of the survey. Item $\mathrm{F}$ has recently been delivered and is discussed in item $\mathrm{G}$, the mission summary report.

This mission summary report includes the following elements:

A. A summary description of the MSS and aerial photographic mission at the RFETS.

B. A brief overview of the scanner system and data format.

C. A description of the analysis procedures used to prepare the seep enhancement.

D. A description of the MSS and photointerpretations used to create the vegetation and hydrology maps.

E. GIS-mapping products. Three examples of the GIS mapping products are included in this report (see Figures 1,7, and 8). The site boundary coverage was provided by RFETS personnel in ARC/INFO format.

Additional data products from this mission can be made available. These are briefly described in the following section.

\subsection{Optional Products}

Proof books of the aerial photographs are available from the RSL. Specific photos in these books can be identified by the unique roll and frame identifier imprinted along the top edge of the photo. Original photography is archived at the RSL, and copies or enlargements of aerial photographs can be produced by the RSL Photo/Video section.

The selected examples of multispectral data presented in this report illustrate the capability of scanner imagery for detecting seeps and springs. MSS imagery can be processed for a wide variety of applications. These products may be requested in digital form (tape or optical disk format), as photographically reproduced images such as those presented in this report, or as extensive analytical reports. Some products can be prepared with a minimum of direction from the end user. Others may require significant interaction with site personnel and/or scientists from multiple disciplines. Field visits by the image analysts are often involved to improve site familiarity.

\subsection{MSS SYSTEM}

The Daedalus AADS1268 MSS is an airborne electrooptical scanner system of proven quality and usefulness for the environmental remote sensing community. It is one of three Daedalus scanners maintained and operated by the RSL for DOE applications. These MSS systems are flown on a regular basis and the collected data are used for a variety of environmental and target signature applications.

For some applications, the features of the airborne scanners operated by the RSL offer major advantages over traditional aerial photography and commercial remote sensing satellites. The scanners collect spectral responses 
at wavelengths that are impossible to collect with aerial photography. By flying at lower altitudes, the scanners can also collect data with finer spatial resolution than that available from commercial satellites.

The manufacturer's nominal system specifications for the instrument flown during the RFETS survey are summarized in Table 1. The measured channel sensitivities are provided in Table 2.

The scanner contains four detector packages with a total of eleven discrete elements (see Figure 2). Reflected and/or emitted electromagnetic energy enters the scanner from the bottom and strikes a rotating "axe blade" mirror, which reflects the energy into the detector housing. Within the housing, a prism and a series of dichroic filters spectrally decompose the energy onto the detectors.

Channels 1 through 8 are generated by a single silicon detector array. This array is contained in an integrated circuit-like package. The middle infrared signals (channels 9 and 10) and the TIR signals (channels 11 and 12) are generated by three detectors, each contained in a separate dewar filled with liquid nitrogen. The liquid nitrogen is used to cool the detectors, increasing their sensitivity and reducing detector noise. The signal from the TIR detector is distributed to two channels. The first channel has a low-gain amplifier that allows for a broad dynamic range, and the second has a higher-gain amplifier for increased sensitivity.

Electromagnetic energy striking the detectors produces a photovoltaic effect proportional to the number of photons striking at a given instant. The signal is amplified and converted into an 8-bit digital value, which is then recorded onto a high-density digital tape (HDDT). The resulting spatial array of data represents a two-dimensional image proportional to the reflectance or emitted energy of the scene features. The scanner has selectable scan rates (up to 100 scan lines per second), which are necessary to ensure contiguous coverage from different altitudes and relative ground speeds.

\subsection{MSS AND PHOTO DATA ACQUISITION}

The MSS imagery and vertical photography were acquired simultaneously during the RFETS survey. The survey was flown with a Convair CV-580, a medium-sized, twin-engine aircraft modified with multiple ports

\section{Table 1. Daedalus AADS1268 MSS Specifications}

\begin{tabular}{l|l}
\hline Number of Channels & 12 \\
Operating Wavelengths & 0.42 to 12.5 micrometers \\
Scan Rate & $12.5,25,50$, or 100 scans per second (selectable) \\
Instantaneous Field of View & 2.5 milliradians (1.25 mrad half-angle mode) \\
Total Field of View & 85.92 degrees \\
Temperature Resolution & 0.1 degrees Centigrade \\
Roll Correction & \pm 15 degrees \\
Reference Sources & Two controllable thermal blackbodies \\
Video Words per Scan Line & 716 \\
Digitizer Gains & $0.5,1,2,4$, or 8 (selectable) \\
\hline
\end{tabular}


Table 2. Measured Spectral Sensitivity of Daedalus AADS1268 MSS System

\begin{tabular}{|c|c|c|}
\hline \multicolumn{3}{|c|}{ Daedalus AADS1268 } \\
\hline $\begin{array}{l}\text { Channel } \\
\text { Number }\end{array}$ & $\begin{array}{l}\text { Wavelength } \\
\text { (m) }\end{array}$ & $\begin{array}{c}\text { Color } \\
\text { Spectrum }\end{array}$ \\
\hline 1 & $0.42-0.44$ & Violet/Blue \\
\hline 2 & $0.46-0.51$ & Blue/Green \\
\hline 3 & $0.52-0.59$ & Green/Yellow \\
\hline 4 & $0.59-0.62$ & Orange \\
\hline 5 & $0.62-0.67$ & Red \\
\hline 6 & $0.67-0.72$ & Near Infrared \\
\hline 7 & $0.73-0.85$ & Near Infrared \\
\hline 8 & $0.84-0.97$ & Near Infrared \\
\hline 9 & $1.59-1.79$ & Middle Infrared \\
\hline 10 & $2.1-2.4$ & Middle Infrared \\
\hline 11 & $8.28-10.67$ & Thermal Infrared \\
\hline 12 & $8.28-10.67$ & Thermal Infrared \\
\hline \multicolumn{3}{|c|}{ Alternate Configuration } \\
\hline 10 & \multicolumn{2}{|l|}{ Empty } \\
\hline 11 & $3.16-5.20$ & Thermal Infrared \\
\hline 12 & $8.28-10.67$ & Thermal Infrared \\
\hline
\end{tabular}

in the floor to accommodate remote sensing equipment. Sky conditions were clear, but summer thermals combined with the high-base altitude created substantial air turbulence during the afternoon acquisition. The flight altitudes were the lowest allowable under standard Federal Aviation Administration rules for safe flight.

\subsection{MSS Acquisition}

The RFETS and the buffer zone were covered by three parallel flight lines acquired during the morning of June 6, 1994. These lines were flown at 4500 feet (1372 meters) AGL with east-west headings. The nominal spatial resolution of scanner pixels at this altitude was approximately 11.25 feet (3.4 meters). These data were acquired to match similar MSS data acquired in June 1989 for temporal comparison. The RFETS and buffer zone were covered by ten parallel flight lines flown at 2000 feet ( 609 meters) AGL with east-west headings. These data were acquired in the morning of June 5,1994 . The nominal spatial resolution at this altitude was approximately 5 feet ( 1.5 meters). These data were acquired for the sitewide vegetation and hydrology mapping effort. 


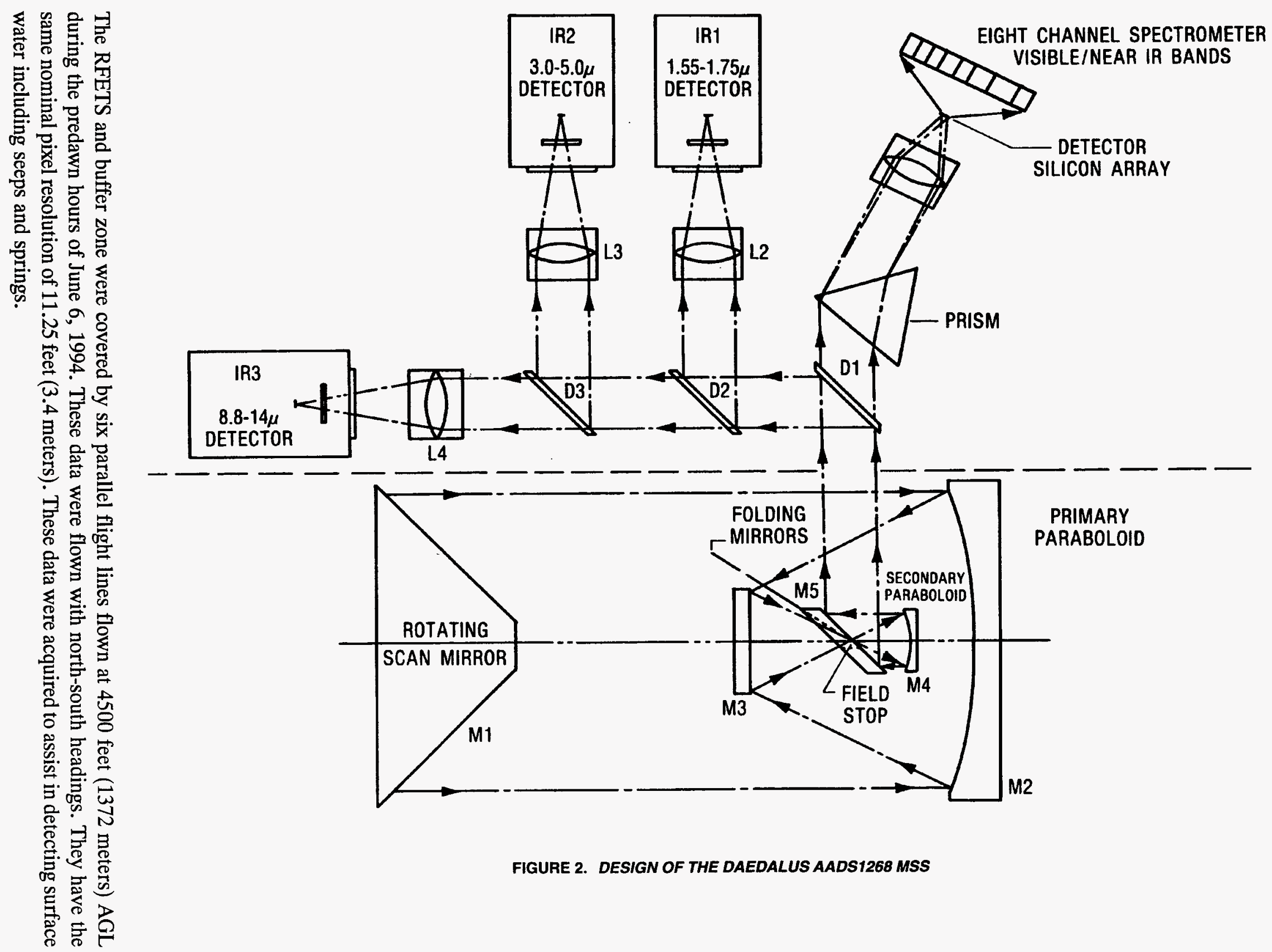


Five sites were selected for special data acquisition. Three sites were flown at 1000 feet (304 meters) including Rock Creek, the proposed landfill, and Woman Creek. These data have a nominal pixel resolution of 2.5 feet (approximately .75 meters). Due to aviation safety concerns, the two flight lines over the A and B ponds were flown at 1500 feet ( 457 meters) with a nominal spatial resolution of 3.75 feet (1.1 meters). These data were acquired during the morning of June 6,1994, and reflown in the afternoon of June 7. All data were acquired on flight lines following the direction of the drainage. These data were acquired by special request from DOE and RFETS personnel to cover sites of special interest where higher-spatial resolution was required. The locations of the flight lines are plotted on the RFETS maps presented in Figures 3 through 5.

\subsection{Photo Acquisition}

A Wild Heerbrugg RC-10 metric-mapping camera was used to acquire large-format (9-inch or 228-millimeter) photographs of the site and surrounding area during the MSS data acquisition. Six-inch (153-millimeter) lenses were used with Aerocolor film for color photography and Aerochrome infrared (IR) film for CIR photography. Photo scales of 1:2000 through 1:9000 resulted from the altitudes that were flown. All photos were collected with standard 60 percent endlap to facilitate stereoscopic viewing and sufficient sidelap ( 30 percent) to ensure contiguous coverage. The photos are of general utility as well as a valuable aid for MSS image analysis.

\subsection{Flight-Line Summary}

A summary of the flight-line specifications is presented as Table 3 . The flight-line index system is based on a combination of identifiers. The first four columns in the table provide information needed to uniquely identify each data set. The first, second, and fourth columns are for the date, time (24-hour clock), and target or site location. The third column lists the run and line number combination. The following explanation of log notations is provided for the reader who wishes to investigate specific areas of coverage using the tables.

The run number is a sequential number advanced after each flight line by the scanner operator and imbedded in the data housekeeping. It usually begins at number 11 when a new tape is started. The next number will identify the blank period on the tape before the next flight line of data, hence the skipping of numbers in the sequence. Aborted or bad lines that are not listed in a final version of the data acquisition table will cause other skipped numbers. It is normal to have more than one "Run 11" during a mission as multiple HDDTs are typically used.

The line number is a reference to the MRS (Microwave Ranging System) navigational system alignment. To set up the MRS program, it is necessary to first identify an axis or "0" flight line. The 0 line is the one from which all other parallel lines are referenced. The 0 line is selected prior to the survey and can be anywhere within or outside the survey area as long as it has the correct heading.

All other parallel flight lines to be flown will become offsets to the 0 line. Normally, each incremental number from the 0 or axis line represents 1000 feet ( 304 meters). A survey designed for complete coverage with multiple parallel flight lines is typically set up so that the line spacing is equal to the altitude above ground. Therefore, if an altitude of 5000 feet (1524 meters) is desired (providing a nominal pixel resolution of 12.5 feet or 3.8 meters), a line spacing of 5000 feet (1524 meters) is selected. The line numbers then increment by 5 (i.e., -5 , $0,+5,+10$, etc.). Therefore, a +5 line will be offset by 5000 feet ( 1524 meters) to one side of the 0 line, and a -10 will be an offset on the opposite side of the axis line by 10000 feet ( 3048 meters). 


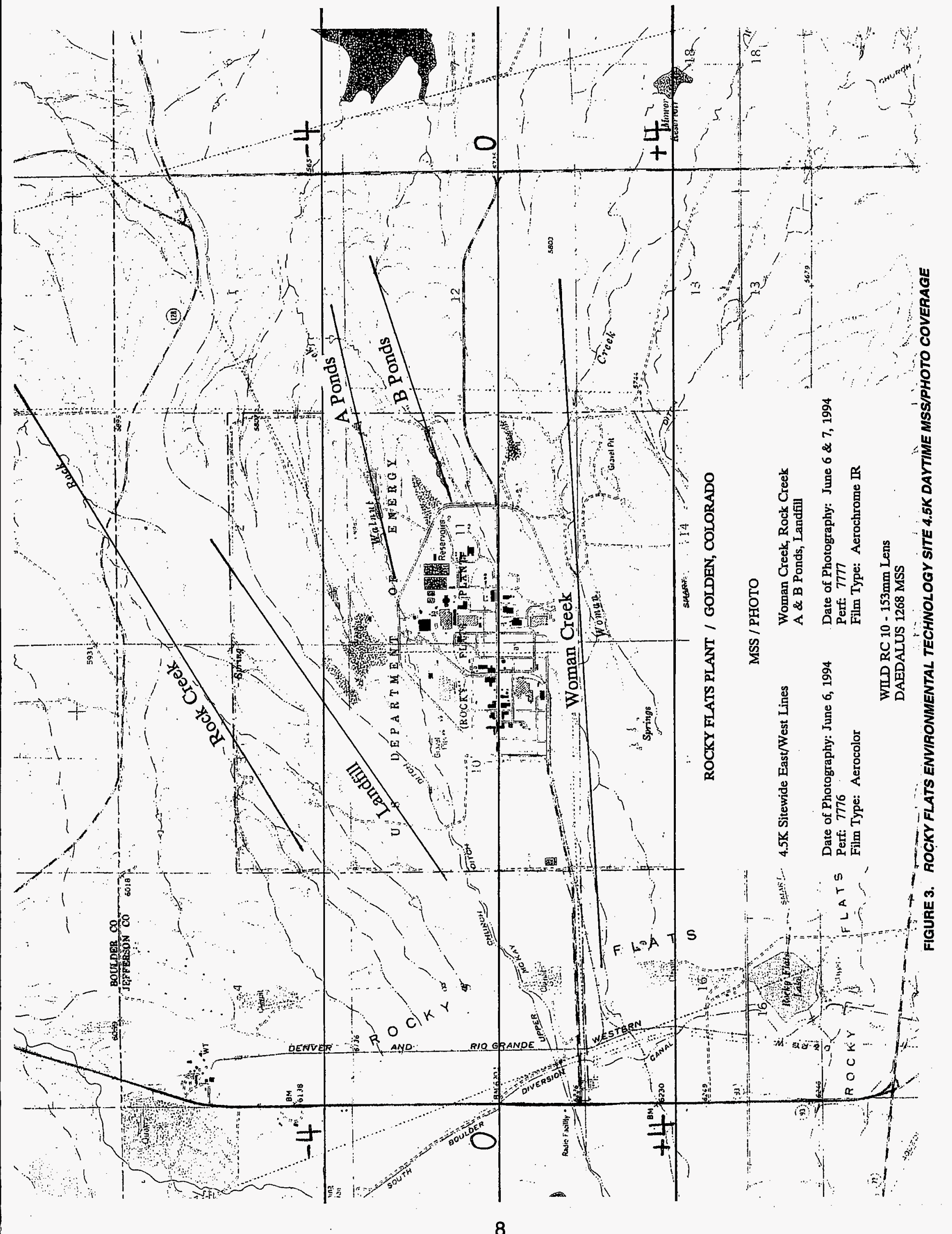




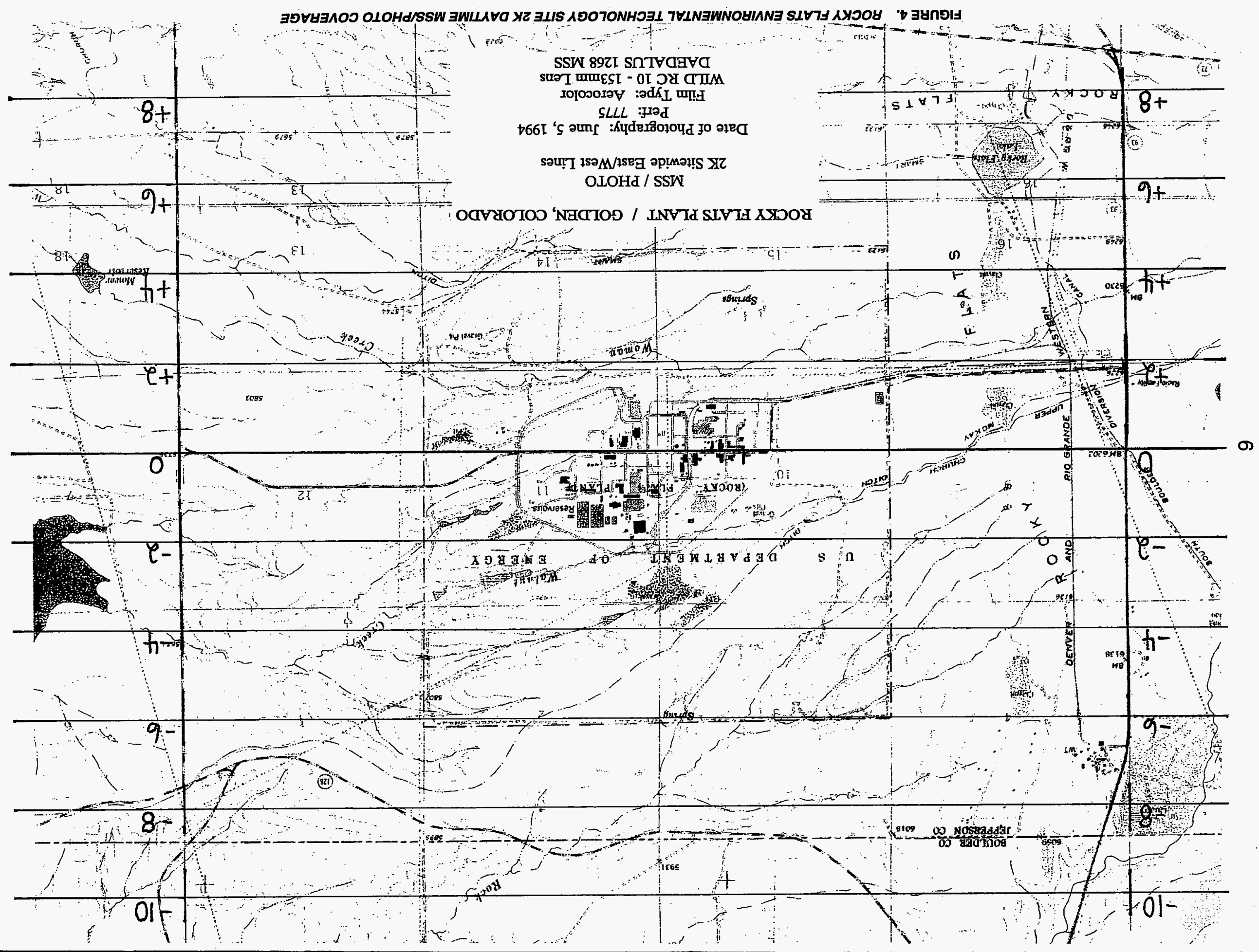


Table 3. Multispectral and Photo Summary - Rocky Flats - June 1994a

\begin{tabular}{|c|c|c|c|c|c|c|c|c|}
\hline Date & Time & $\begin{array}{l}\text { MSS } \\
\text { Run }\end{array}$ & Target & AGt: & $\begin{array}{l}\text { True } \\
\text { Head }\end{array}$ & $\begin{array}{l}\text { Photo } \\
\text { Perf. No. }\end{array}$ & $\begin{array}{l}\text { Photo } \\
\text { Frames }\end{array}$ & Comments \\
\hline June 3 & $\begin{array}{l}1329 \\
1335 \\
1346 \\
\\
1354 \\
1411 \\
1422\end{array}$ & $\begin{array}{l}11 / 0 \\
13 / 0 \\
15 /-2 \\
17 / 0 \\
19 / 0 \\
21 /-6\end{array}$ & $\begin{array}{l}\text { E-W Axis } \\
\text { E-W Line } \\
\text { E-W Line } \\
\text { N-S Axis } \\
\text { N-S Line } \\
\text { N-S Line }\end{array}$ & $\begin{array}{l}2 \mathrm{~K} \\
2 \mathrm{~K} \\
2 \mathrm{~K} \\
2 \mathrm{~K} \\
2 \mathrm{~K} \\
2 \mathrm{~K}\end{array}$ & $\begin{array}{l}270^{\circ} \\
272^{\circ} \\
273^{\circ} \\
001^{\circ} \\
004^{\circ} \\
183^{\circ}\end{array}$ & $\begin{array}{c}\text { None } \\
- \\
- \\
- \\
- \\
-\end{array}$ & $\begin{array}{l}- \\
- \\
- \\
- \\
- \\
-\end{array}$ & $\begin{array}{l}\text { cloud shadows } \\
\text { cloud shadows } \\
\text { cloud shadows } \\
\text { cloud shadows }\end{array}$ \\
\hline June 5 & $\begin{array}{l}0839 \\
0847 \\
0856 \\
0907 \\
0914 \\
0921 \\
0928 \\
0934 \\
0937 \\
0941 \\
\end{array}$ & $\begin{array}{l}31 \\
33 /+8 \\
35 /+6 \\
\\
37 /+4 \\
39 /+2 \\
41 / 0 \\
43 /-2 \\
45 /-4 \\
47 /-6 \\
49 /-8 \\
51 /-8 \\
53 /-10 \\
55\end{array}$ & $\begin{array}{l}\text { E-W Line } \\
\text { E-W Line } \\
\text { E-W Line } \\
\text { E-W Line } \\
\text { E-W Line } \\
\text { E-W Line } \\
\text { E-W Line } \\
\text { E-W Line } \\
\text { E-W Line } \\
\text { Panels }\end{array}$ & $\begin{array}{l}2 \mathrm{~K} \\
2 \mathrm{~K} \\
2 \mathrm{~K} \\
2 \mathrm{~K} \\
2 \mathrm{~K} \\
2 \mathrm{~K} \\
2 \mathrm{~K} \\
2 \mathrm{~K} \\
2 \mathrm{~K} \\
2 \mathrm{~K}\end{array}$ & $\begin{array}{l}274^{\circ} \\
276^{\circ} \\
276^{\circ} \\
274^{\circ} \\
274^{\circ} \\
274^{\circ} \\
275^{\circ} \\
274^{\circ} \\
276^{\circ} \\
093^{\circ}\end{array}$ & $\begin{array}{l}7775 \\
7775 \\
7775 \\
7775 \\
7775 \\
7775 \\
7775 \\
7775 \\
7775 \\
7775\end{array}$ & $\begin{array}{r}001-006 \\
007-023 \\
025-042 \\
043-060 \\
061-078 \\
079-096 \\
097-114 \\
115-132 \\
133-150 \\
151-170 \\
- \\
171-186 \\
187-192\end{array}$ & $\begin{array}{l}\text { natural color film, } f 41 / 800 \\
\text { could not level camera } \\
\text { noise in MSS }\end{array}$ \\
\hline June 6 & $\begin{array}{l}0410 \\
0418 \\
0425 \\
0432 \\
0440 \\
0448 \\
\\
0456\end{array}$ & $\begin{array}{l}11 /-12 \\
13 /-16 \\
15 /-8 \\
17 /-8 \\
19 /-4 \\
21 / 0 \\
23 /+4\end{array}$ & $\begin{array}{l}\mathrm{N}-\mathrm{S} \text { Line } \\
\mathrm{N}-\mathrm{S} \text { Line } \\
\mathrm{N}-\mathrm{S} \text { Line } \\
\mathrm{N}-\mathrm{S} \text { Line } \\
\mathrm{N}-\mathrm{S} \text { Line } \\
\mathrm{N}-\mathrm{S} \text { Line } \\
\mathrm{N}-\mathrm{S} \text { Line }\end{array}$ & $\begin{array}{l}4.5 \mathrm{~K} \\
4.5 \mathrm{~K} \\
4.5 \mathrm{~K} \\
4.5 \mathrm{~K} \\
4.5 \mathrm{~K} \\
4.5 \mathrm{~K} \\
4.5 \mathrm{~K}\end{array}$ & $\begin{array}{l}358^{\circ} \\
002^{\circ} \\
002^{\circ} \\
002^{\circ} \\
001^{\circ} \\
001^{\circ} \\
001^{\circ}\end{array}$ & $\begin{array}{l}- \\
- \\
- \\
- \\
- \\
- \\
-\end{array}$ & $\begin{array}{l}- \\
- \\
- \\
- \\
- \\
-\end{array}$ & $\begin{array}{l}\text { predawn } \\
\text { some sat. channel } 12 \\
\text { slight bounce in MSS } \\
\text { repeat, change speed }\end{array}$ \\
\hline June 6 & $\begin{array}{l}0817 \\
0836 \\
0842 \\
0847 \\
0853 \\
0901 \\
0906 \\
0911 \\
0926\end{array}$ & $\begin{array}{l}31 \\
33 \\
35 \\
37 \\
39 \\
41 \\
43 \\
45 \\
47 /+4 \\
49 / 0 \\
51 /-4\end{array}$ & $\begin{array}{l}\text { Panels } \\
\text { Woman Creek } \\
\text { Landfill } \\
\text { Rock Creek } \\
\text { A Ponds } \\
\text { B Ponds } \\
\text { Landfill } \\
\text { Rock Creek } \\
\text { E-W Line } \\
\text { E-W Line } \\
\text { E-W Line }\end{array}$ & $\begin{array}{l}2 \mathrm{~K} \\
1 \mathrm{~K} \\
1 \mathrm{~K} \\
2 \mathrm{~K} \\
1.5 \mathrm{~K} \\
1.5 \mathrm{~K} \\
1 \mathrm{~K} \\
2 \mathrm{~K} \\
4.5 \mathrm{~K}\end{array}$ & $\begin{array}{l}093^{\circ} \\
090^{\circ} \\
069^{\circ} \\
054^{\circ} \\
067^{\circ} \\
052^{\circ} \\
054^{\circ} \\
056^{\circ} \\
272^{\circ} \\
274^{\circ} \\
275^{\circ}\end{array}$ & $\begin{array}{l}7776 \\
7777 \\
7777 \\
7777 \\
7777 \\
7777 \\
7777 \\
7777 \\
7776 \\
7776 \\
7776 \\
\end{array}$ & $\begin{array}{l}001-004 \\
001-036 \\
038-060 \\
061-079 \\
080-092 \\
094-104 \\
105-119 \\
120-135 \\
005-013 \\
014-023 \\
024-031\end{array}$ & $\begin{array}{l}\text { natural color film, } f 41 / 850 \\
\text { CIR film } \\
\text { CIR film } \\
\text { CIR film } \\
\text { CIR film } \\
\text { CIR film } \\
\text { CIR film } \\
\text { CIR film } \\
\text { natural color film, } f 41 / 900 \\
\text { natural color film, } f 41 / 900 \\
\text { natural color film, } f 41 / 900\end{array}$ \\
\hline
\end{tabular}

a Daedalus AADS1268 MSS with spectrometer; 1.6-, 2.2-, and 8-12- $\mu \mathrm{m}$ detectors; 2.5 -mrad instantaneous field of view.

Wild Heerburg RC-10, 153-mm lens, Aerocolor (normal color) negative film, and Aerochrome CIR film. 
Table 3. Multispectral and Photo Summary - Rocky Flats - June 1994a

\begin{tabular}{|c|c|c|c|c|c|c|c|c|}
\hline Date & Time & $\begin{array}{l}\text { MSS } \\
\text { Run }\end{array}$ & Target & $\begin{array}{l}\text { Alt. } \\
\text { AGL }\end{array}$ & $\begin{array}{l}\text { True } \\
\text { Head }\end{array}$ & $\begin{array}{l}\text { Photo } \\
\text { Perf. No. }\end{array}$ & $\begin{array}{l}\text { Photo } \\
\text { Frames }\end{array}$ & Comments \\
\hline \multirow{7}{*}{ June 7} & 0949 & 53 & Panels & $2 \mathrm{~K}$ & $062^{\circ}$ & 7776 & $032-037$ & natural color film, $f 41 / 900$ \\
\hline & 1421 & 61 & B Ponds & $1 \mathrm{~K}$ & $059^{\circ}$ & 7777 & $141-156$ & $\begin{array}{l}\text { turbulent, channel } 12 \text { sat. } \\
\text { CIR film } f 41 / 800\end{array}$ \\
\hline & 1427 & 63 & A Ponds & $1.3 \mathrm{~K}$ & $072^{\circ}$ & 7777 & $157-169$ & early shadows, CIR \\
\hline & 1437 & 65 & Landfill & $1 \mathrm{~K}$ & $053^{\circ}$ & 7777 & $170-193$ & first half shadowed, CIR \\
\hline & 1442 & 67 & Rock Creek & $1 \mathrm{~K}$ & $057^{\circ}$ & 7777 & $194-215$ & cloud shadows, CIR \\
\hline & 1446 & 69 & Rock Creek & $1 K$ & $055^{\circ}$ & 7777 & $216-234$ & half shadows, CIR \\
\hline & 1450 & 71 & Landfill & $1 \mathrm{~K}$ & $054^{\circ}$ & 7777 & $235-255$ & last half shadowed, CIR \\
\hline
\end{tabular}

a Daedalus AADS1268 MSS with spectrometer; 1.6-, 2.2-, and 8-12- $\mu \mathrm{m}$ detectors; 2.5 -mrad instantaneous field of view. Wild Heerburg RC-10, 153-mm lens, Aerocolor (normal color) negative film, and Aerochrome CIR film.

The run/line number combination is only applicable when the scanner and the MRS are both used. A scanner line flown without benefit of the MRS would show only a run number or a run number combined with "vis" for a flight line that was navigated visually. The MRS may also be used for photo collection alone without the MSS, and when this is the case, there will be no run number, just the line number. It is possible that a run number and line number combination will be repeated, making it necessary to use the date and/or time to differentiate between the two. Often, more than one 0 line will also be set up for a mission, making the target or location name also a necessary part of the identifier. To understand where the flight lines are located, a map that has at least the 0 line(s) and the + and - offset direction identified is necessary.

\subsection{MSS DATA PREPROCESSING}

The Daedalus AADS1268 MSS data undergo a series of standard data preprocessing steps prior to analysis. These steps include decommutation, systematic geometric processing, and radiometric calibration of the thermal channels.

\subsection{MSS Data Decommutation}

MSS data recorded on the HDDT must be decommutated prior to digital image processing. Decommutation is the conversion of an analog serial bit data stream to a digital format that is readable by computer. The data are decommutated from the HDDT format into a computer-compatible format. The data are quality checked and then archived to optical disk. The output, raw byte data, can be provided on several different types of media including 8-millimeter and 9-track computer tapes and optical disk. A variety of standard file formats for image processing systems is also available.

\subsection{Geometric Correction}

Prior to analysis, the decommutated data are usually corrected for systematic geometric distortions. ${ }^{2}$ The data are processed to minimize the tangential distortion (S-bend) inherent in electrooptical scanner data and to compensate for any overscan based on the scan rate and velocity-to-height ratio. 


\subsection{Radiometric Calibration}

The channels containing TIR data (channels 11 and 12) were radiometrically calibrated, based on the recorded temperatures of the two internal reference blackbodies. The relative difference in apparent temperature between two features is considered nominally accurate to within one-tenth degree Centigrade. To obtain the absolute temperature of any feature, additional information about atmospheric conditions and the emissivity characteristics of the feature must be known. This usually involves on-site ground temperature measurements during the airborne data acquisitions and was not required for this investigation.

\subsection{MSS IMAGE ENHANCEMENT}

The spectral signals recorded by multispectral scanners have proven useful for characterizing a variety of environmental conditions. As these signals are recorded in digital format, computer-assisted image-processing techniques can be used to enhance specific spectral features and thereby increase the utility of the image products for specific applications.

Interactive digital image analyses were performed on the RFETS data using Hewlett Packard workstations and the EASI-PACE Image Processing system developed by PCI (Ontario, Canada). The image-processing techniques ranged from very simple and straightforward enhancements to complex and iterative-processing algorithms. The systematic application of image-enhancement procedures can benefit by first reviewing the basic phenomenology of the application of interest. The following section briefly addresses the classification of vegetation and the detection of seeps and springs.

\subsection{Background Phenomenology}

The term land cover relates to the type of surficial features present at the time of data acquisition. ${ }^{3}$ Although some features are easily separable (e.g., roads versus water), other features like mesic and xeric grasslands are not as easy to distinguish. The detection and identification of different land-cover types is improved by the use of MSS data because there are ten channels of information versus three components for a color or CIR photograph. The process of using computer-assisted image-analysis procedures to fully evaluate the spectral information and derive land-cover classes is termed spectral pattern recognition. When attempting to classify land cover, it is best to use all means of information that are available including MSS data; color and CIR aerial photography; and mapped geology, soils, hydrology, etc. For this study, vegetation including wetlands and seeps or potential seeps was identified and classified.

At RFETS, there are two predominant grassland types: mesic-mixed and xeric-mixed grasslands. Generally, the mesic grasslands are found on hillsides and are comprised of Agropyron, Bouteloua, and associated grasses. The xeric grasslands occur on flat plateaus and include Andropogon, Stipa, Aristida, Koeleria, and associated grasses. The two types of grasslands are spectrally dissimilar and easily separable using MSS data combined with aerial photography and elevation data.

Wetlands, according to the U.S. Fish and Wildlife Service (USFWS), are “. . . lands transitional between terrestrial and aquatic systems where the water table is usually at or near the surface or the land is covered by shallow water." Wetlands ". . . must have one or more of the following three attributes: at least periodically, the land supports predominately hydrophytes; the substrate is predominately undrained hydric soil; and the substrate is nonsoil and is saturated with water or covered by shallow water at some time during the growing season of each year." 4 A seep, according to the American Geological Institute, is “ . . . an area, generally small, 
where water . . percolates slowly to the land surface."5 Seeps occur when water, percolating through the soil profile, meets an impermeable soil layer and follows that layer contour until the water breaks the surface. This usually is manifested on sloping hillsides and has been observed in the Rock Creek and Woman Creek watersheds.

Using USFWS attributes to define wetlands is too stringent for application to mapping all wetlands using remote sensing techniques. The application of the three attributes can only be done through field inspection and laboratory analysis. Mapping seeps through image analysis can also be difficult and requires the use of indirect techniques. However, suitable image-analysis techniques can be used in conjunction with photogrammetric and photointerpretation techniques to derive accurate wetlands mapping.

Although somewhat similar, the vegetation communities present in wetlands at RFETS do vary in composition and structure. ${ }^{6}$ Two types of wetlands are observed on the site. They include wetlands associated with seeps and springs and wetlands associated with ephemeral stream drainage from the Rocky Mountains to the west.

\subsection{Contrast Enhancements}

When a digital image is created, the quantizing process defines a discrete range of values that are often termed gray or brightness levels. For Daedalus AADS1268 digital imagery, the available brightness levels range from 0 (black or no signal) to 255 (white maximum signal). Sensor-gain levels are usually set to span the full range of conditions that might be present on each flight line of data collection in order to obtain data without clipping (low end) or saturation (high end).

The apparent contrast (or relative difference.in brightness values) between specific scene features can often be improved by applying digital contrast enhancement. Contrast enhancement takes a narrow range of raw data and stretches it to cover the full potential range of the display device. This allows subtle differences in tone between different features on the ground to be emphasized and become more visually apparent. All of the examples shown in the following sections have been contrast enhanced.

\subsection{MSS Color Composites}

The visual perception of color is usually more acute than for shades of gray. Computer monitors and film recorders use three-color signals to create color composite images. Various image-processing procedures are available to select and combine multispectral imagery into color composites.

\subsubsection{Standard Color Composites}

A standard color composite image is a three-channel combination of different MSS channels. The color of features in a standard composite image is a function of relative radiance differences in the spectral channels selected for the composite. When the Daedalus AADS1268 channels equivalent to the red, green, and blue wavelengths (channels 5,3 , and 2 , respectively) are combined and displayed in the corresponding colors, the result is analogous to a color photograph. In this type of composite, commonly called a natural color composite, the colors of scene features are similar to the colors as they would appear visually or in color photography. The upper left image presented in Figure 6 is an example of a natural color composite from the 1372-meter (4500-foot) RFETS data set.

Any three MSS channels, including the thermal channel, can be used to produce a MSS color composite. A standard approach is to select a channel combination that produces the most color separation between the 


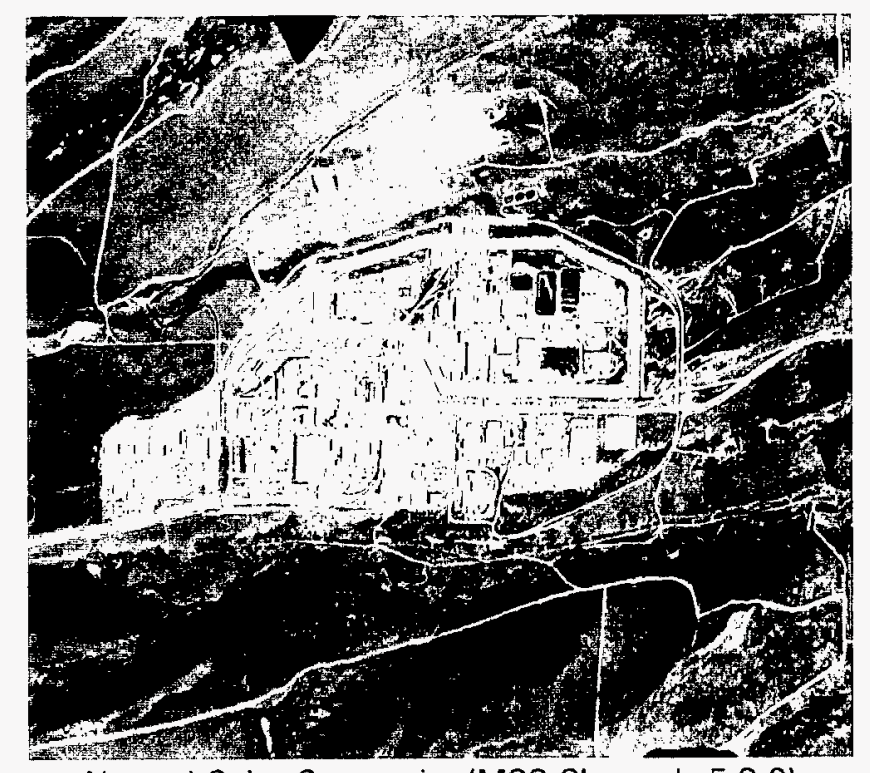

Natural Color Composite (MSS Channels 5,3,2)

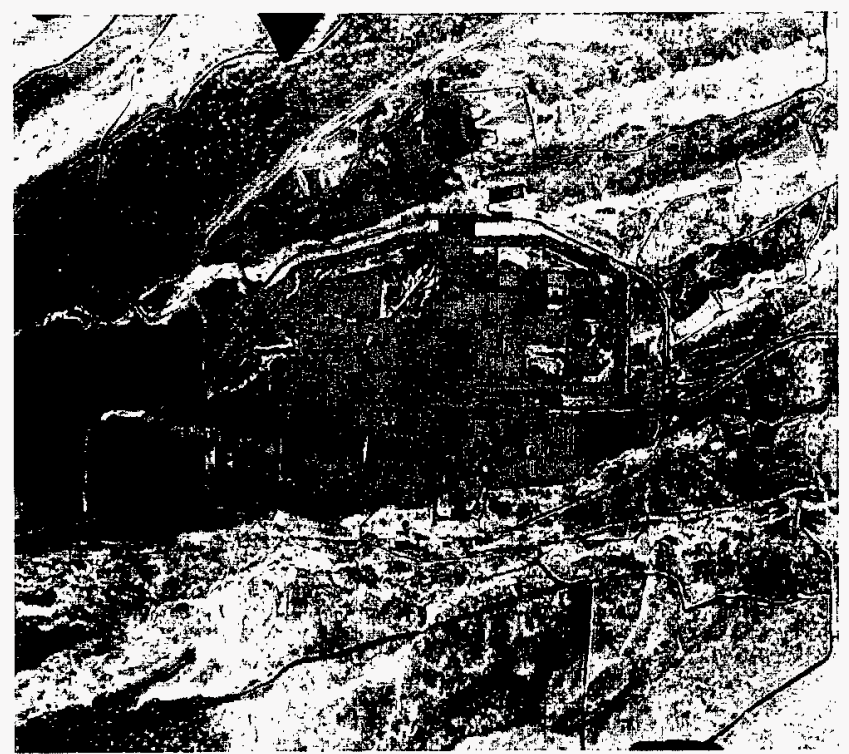

Kauth/Thomas Transformation

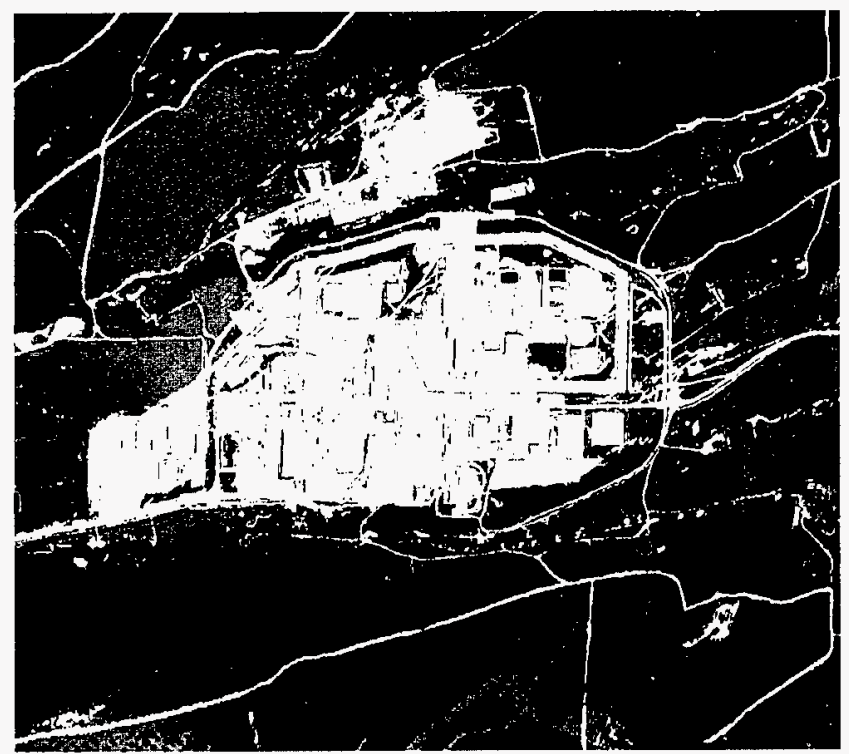

Unsupervised Clustering (32 clusters)

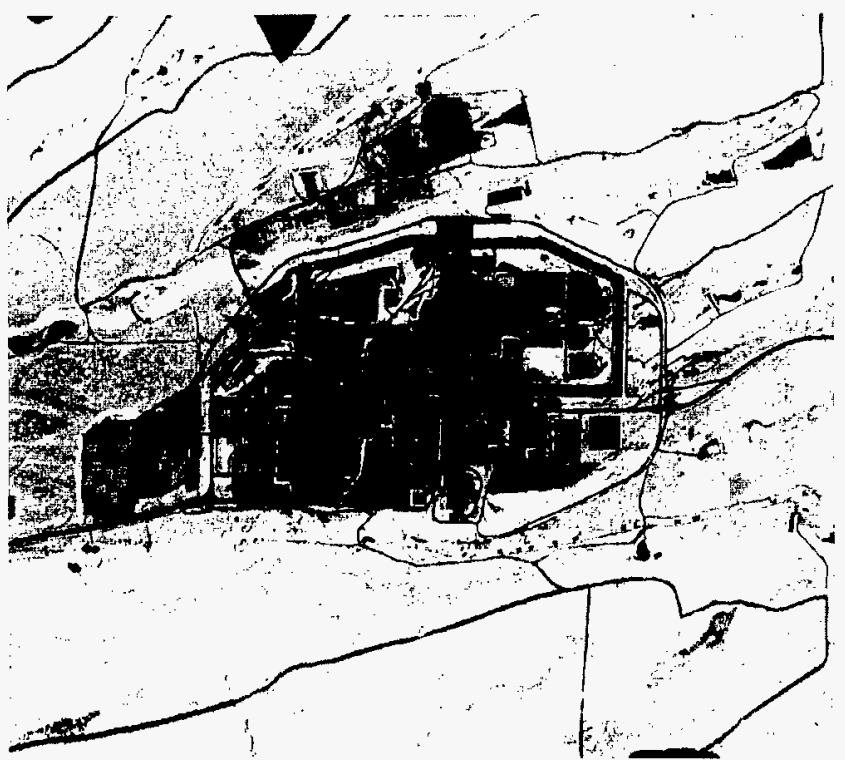

Normalized Difference Vegetation Index (NDVI)

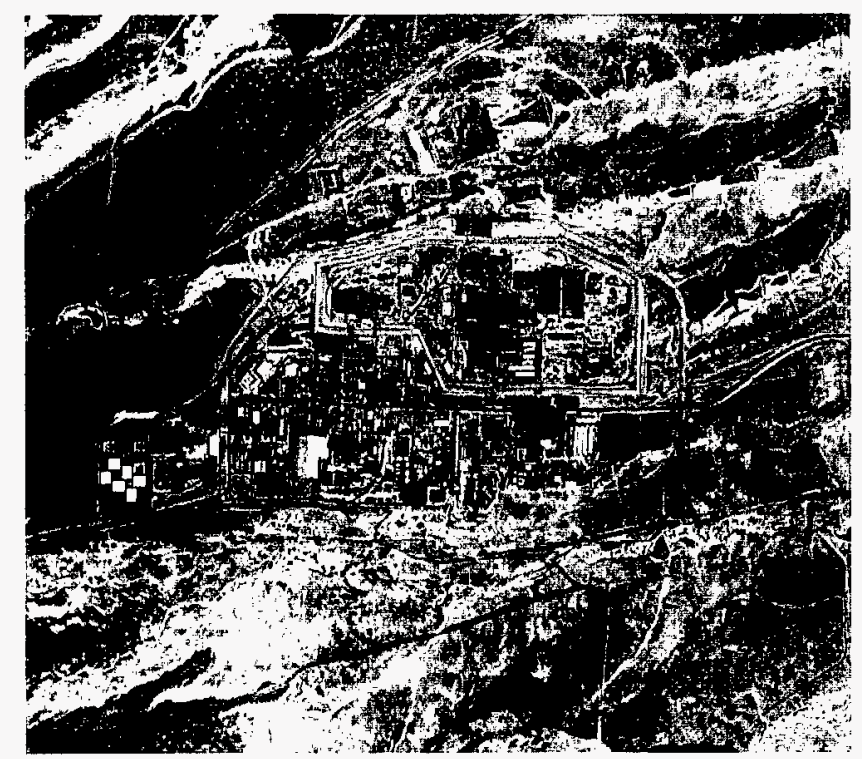

Seeps Enhancement (MSS Channels 11,7,5)
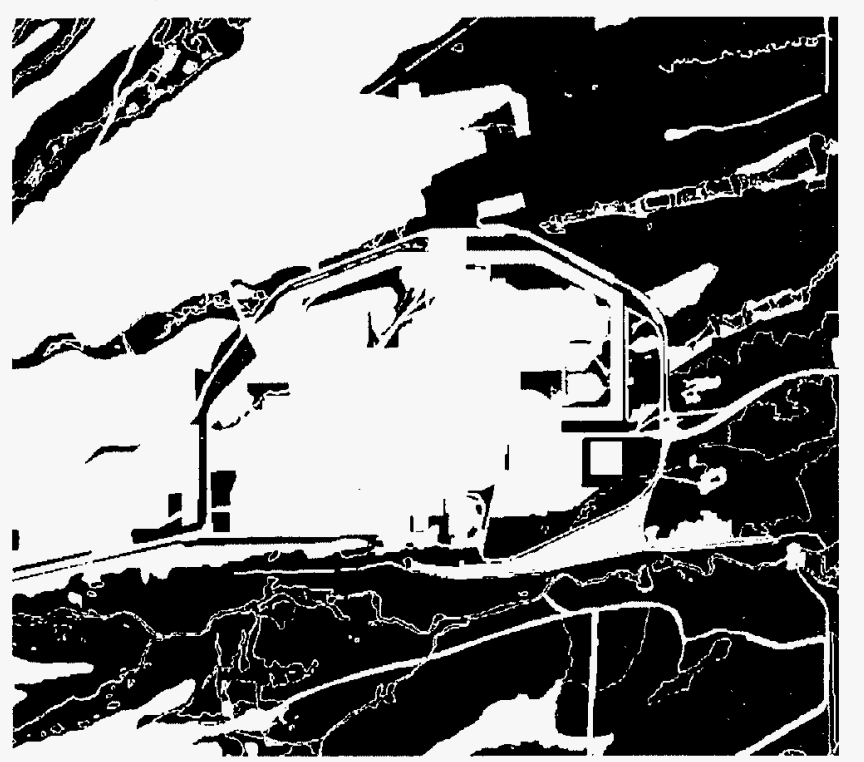

Vegetation Classification

FIGURE 6. DATA MOSAIC (COLOR PHOTO/VEGETATION-ENHANCED/CLUSTER/FINAL MAP) 
features of interest and the background. Several techniques have been developed to facilitate this process of channel selection.

\subsubsection{Vegetation Enhancement - Normalized Difference Vegetation Index}

Many spectral ratios have been investigated for measuring vegetation density, and the normalized difference vegetation index (NDVI) is demonstrated by the upper right image in Figure $6 .{ }^{7}$ This image was created by dividing the difference between MSS channels 7 and 5 by the sum of MSS channels 7 and 5 and normalizing the result. The lightest shades of gray are the most heavily vegetated areas while the darker grays and black indicate the least amount of vegetation.

\subsubsection{Vegetation Enhancement - Kauth/Thomas Transformation}

Another useful vegetation enhancement is the Kauth/Thomas Transformation or Tasseled Cap Transformation. ${ }^{8}$ This transformation rotates the data so that the majority of the data is represented in the first two resultant channels. These channels are commonly referred to as the brightness and greenness channels. An example of the transformation applied to the RFETS data is represented by the left middle image of Figure 6 . The plant site and the road network are red because they have a large brightness component (red channel) and no vegetation component (green channel). The highly vegetated areas are shades of green because they have a low-brightness component and a high-vegetation component.

\subsubsection{Seep Enhancement}

A useful image enhancement for detecting seeps involves combining a thermal channel, a mid-infrared channel, and a red channel. This enhancement brings out subtle differences in vegetation types and indicates the presence of water. The enhancement was generated by (a) inverting the mapping on channel 11 and displaying the result as the red signal, (b) displaying channel 7 as green, and (c) displaying channel 5 as blue.

The image was then contrast-stretched to further enhance subtle details. The right middle image of Figure 6 represents an example of this seep enhancement. By inverting the thermal data, the presence of water is indicated by the amount of red that is present. Unfortunately, shadows in the thermal data are also enhanced and can become a source of confusion. Color aerial photographs, when viewed in stereo, can help eliminate this potential confusion. The vegetation in the image is enhanced by displaying the mid-infrared channel as green. A higher vegetation content correlates with a higher green response on the image. When you have both high red (moisture) and high green (vegetation), then the resultant wet vegetation will appear as yellow. When the yellow areas are away from stream corridors and on sloping hillsides, they are excellent indicators for identifying potential seeps. Although the vegetation types are seen in color aerial photographs, the extent of the moisture is not as apparent, and it is the combination of the two features that is very useful in identifying seeps and springs.

\subsection{IMAGE ANALYSIS AND PHOTOINTERPRETATION}

\subsection{Image Analysis}

Image-analysis techniques were used to classify and map the MSS data for vegetation, wetlands, and seeps. Multitemporal Daedalus AADS1268 MSS data were used in the image analysis. 


\subsubsection{Image Analysis for Vegetation}

Although it was originally envisioned that the vegetation classification would be accomplished using digital techniques, several technical difficulties prevented the MSS data from being the primary source for the vegetation classification. These difficulties included off-angle illumination effects, sun-angle variations during the data collection, and bidirectional reflectance changes based on vegetation types and slope. As a result, the vegetation classification was completed using aerial photointerpretation, and the MSS data were used as collateral data in support of the interpretation.

\subsubsection{Image Analysis for Seeps and Wetlands}

The seep-enhancement imagery described in Section 5.3.1 was used as input to the analysis for seeps and wetlands. The seep-enhancement imagery was interpreted in a multilayered approach. Large areas representing zones for potential seep occurrences were broadly mapped. These zones encompass primarily yellow-green to yellow-orange hues as well as yellow-orange to orange-red hues.

Selected upper reaches of these potential seep-occurrence zones were mapped as lines of seep occurrence as were isolated point sources for seep occurrence. These linear and point features encompass yellow-orange to red hues on the seep-enhancement imagery.

\subsection{Photointerpretation for Vegetation and Wetlands}

Photointerpretation of natural color photographs was the primary method for mapping vegetation and wetlands. As stated earlier, the nature of the biotic zone (i.e., grasslands) and the peculiarities of working with multiple lines of MSS data did not lend itself to an automated approach to mapping vegetation and wetlands.

The entire RFETS was photographed using natural color aerial photography acquired on June 5, 1994, at a scale of 1:4000. Additional CIR photography acquired over the streams, ponds, and landfill on June 6 and 7 , 1994 , at a scale of 1:2000 to $1: 4000$ were also used.

A modified version of the vegetation classification scheme used on the 1992 "Vegetation at Rocky Flats Plant"9 map was used for mapping. Table 4 shows the original and the new classification scheme used for this mapping project as shown on the map in Figure 7. Wetlands were not mapped separately but as members of the vegetation classes. Seeps, at this stage, are considered a subclass of wetlands overall. Spatial analysis as well as remote sensing and image-analysis techniques were used to map potential seeps and seep occurrences.

Three photointerpreters were used to interpret and map the vegetation and wetland classes on clear mylar sheets overlaid on the aerial photographs. Each interpretation was mapped on one of the photographs of each stereo pair. The CIR photography and the printed and classified MSS imagery were used as corroborative data sources.

The minimum-mapping unit used was 0.1 inches (.254 centimeters) on the map or 33.3 feet (10.16 meters) on the ground. Polygonal features that fit within a square of 0.1 by 0.1 inches were not mapped. Elongated polygonal features that were narrower than 0.1 inches and more than 100 times 0.1 inches (i.e., more than 10 inches or 25.4 centimeters long) were mapped.

A review of the photointerpretations was performed during the data-automation phase to verify accuracy and completeness in the delineation and assignment of classes. 
Table 4. Vegetation Classification Schemes ${ }^{\mathrm{a}}$

\begin{tabular}{|c|c|}
\hline Old Vegetation Classification & New Vegetation Classification \\
\hline $\begin{array}{l}\text { Wetland Habitats } \\
\text { Wet Meadow/Marsh Ecotone } \\
\text { Short Marsh } \\
\text { Tall Marsh } \\
\text { Open Water }\end{array}$ & $\begin{array}{l}\text { Wet Meadow/Marsh Ecotone } \\
\text { Short Marsh } \\
\text { Tall Marsh } \\
\text { Open Water }\end{array}$ \\
\hline $\begin{array}{l}\text { Woodland Habitats } \\
\text { Deciduous Woodland } \\
\text { Ponderosa Woodland } \\
\text { Tree Plantings } \\
\end{array}$ & $\begin{array}{l}\text { Riparian Woodland } \\
\text { Ponderosa Woodland } \\
\text { (Not Mapped) }\end{array}$ \\
\hline $\begin{array}{l}\text { Shrubland Habitats } \\
\text { Bottomland Shrubland } \\
\text { Bottomland Shrubland } \\
\text { Bottomland Shrubland } \\
\text { Upland Shrub, Short } \\
\text { Upland Shrub, Tall } \\
\end{array}$ & $\begin{array}{l}\text { Riparian Shrubland } \\
\text { Riparian Shrubland, Riverine } \\
\text { Riparian Shrubland, Palustrine } \\
\text { Upland Shrubland, Short } \\
\text { Upland Shrubland, Tall } \\
\end{array}$ \\
\hline $\begin{array}{l}\text { Grassland Habitats } \\
\text { Short Grass } \\
\text { Mesic-Mixed Grassland } \\
\text { Xeric-Mixed Grassland } \\
\text { Reclaimed Mixed Grass } \\
\end{array}$ & $\begin{array}{l}\text { Mesic-Mixed Grass } \\
\text { Mesic-Mixed Grass } \\
\text { Xeric-Mixed Grass } \\
\text { Reclaimed Mixed Grass }\end{array}$ \\
\hline $\begin{array}{l}\text { Disturbance Categories } \\
\text { Disturbed Area - Annual Grass/Forb } \\
\text { Disturbed Area - Disturbed/Barren Lands } \\
\text { Disturbed Area - Developed Areas }\end{array}$ & $\begin{array}{l}\text { Disturbed or Developed Lands } \\
\text { Disturbed or Developed Lands } \\
\text { Disturbed or Developed Lands }\end{array}$ \\
\hline
\end{tabular}

\subsection{DATA AUTOMATION, DATA ANALYSIS, AND MAP PRODUCTION}

\subsection{Data Automation}

\subsubsection{Vegetation and Wetlands}

The photointerpretation products were digitized into a GIS, using the Environmental Systems Research Institute's ARC/INFO GIS. The data collected and mapped by the U.S. Army Corps of Engineers was integrated into the new vegetation coverage using the classification conversions shown in Table 5.

Where a wetlands code, for example, the PEM codes, correlates to more than one vegetation class, the assigned class was designated by stereographic photointerpretation of the vegetation unit. The Corps' wetlands classifications were incorporated into the new vegetation coverage. Through this work, the conditions that 

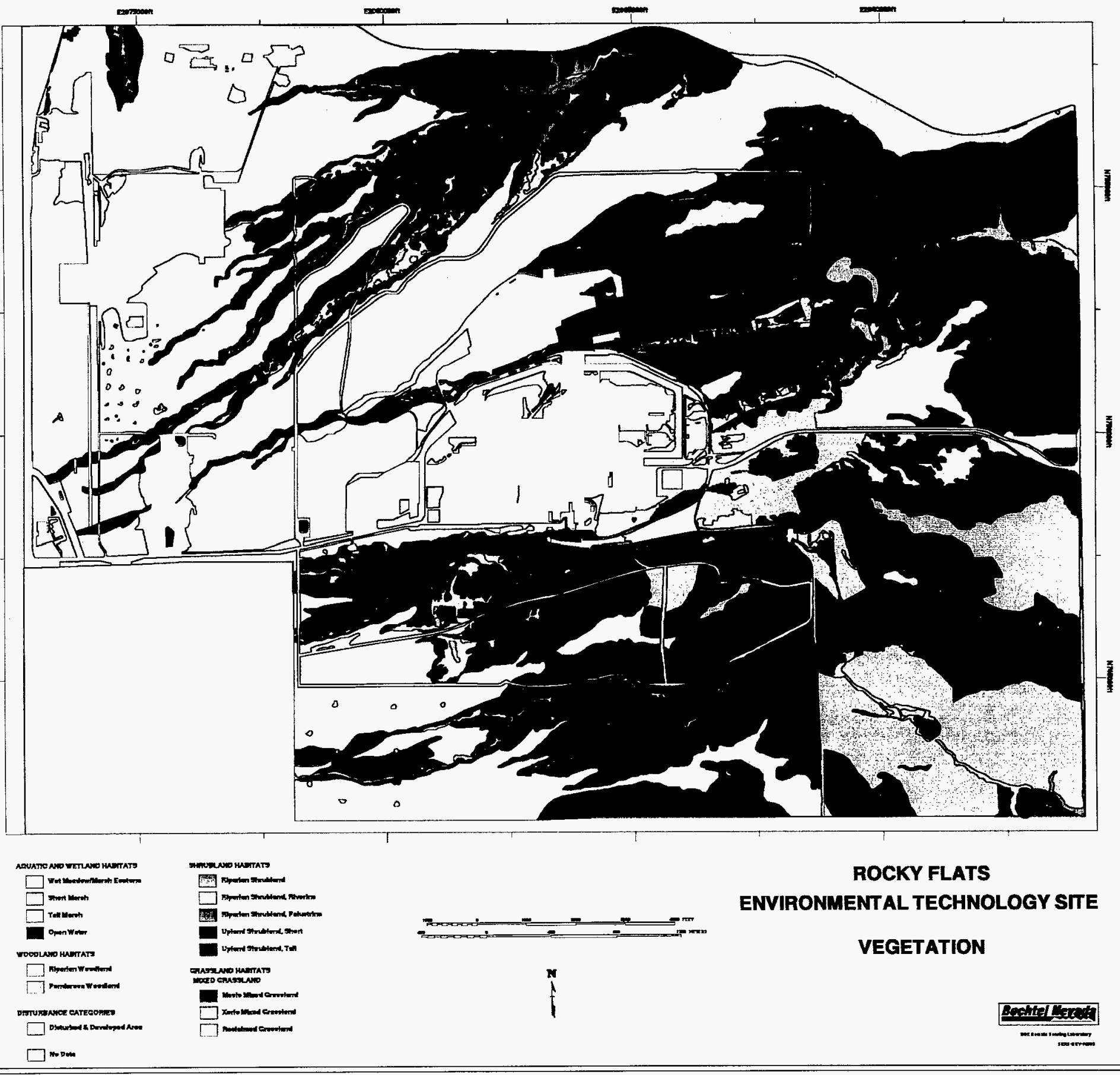

ROCKY FLATS

ENVIRONMENTAL TECHNOLOGY STTE

VEGETATION

FIGURE 7. VEGETATION MAP OF THE ROCKY FLATS ENVIRONMENTAL TECHNOLOGY SITE

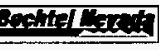


existed during the aerial survey were mapped. Therefore, where the photointerpretion was substantially different from the Corps' classification, the new interpretation was used in the vegetation coverage. This essentially expanded the wetlands mapped by the Corps.

The interpreted vegetation polygons were digitized by a heads-up ARC/EDIT display where the digital orthophoto was used as a backdrop and base map. An analyst who was not involved in the photointerpretation and automation did the final review and editing of the new vegetation coverage.

The final, new vegetation coverage had a look-up table designed for producing hard-copy output that emulated the "Vegetation at Rocky Flats Plant"9 map. The coverage was documented through ARC/INFO's metadata generation utility. The final vegetation coverage is "rfveg96" and the Federal Geographic Data Committee-compliant metadata file is "rfveg96.fgdc." A map developed from "rfveg96" is shown in Figure 7.

\subsubsection{Seeps}

The identification and delineation of seeps were automated from interpreted MSS seep-enhancement images. Large, mapped, potential seep-occurrence zones, seep lines, and seep points were interpreted by the image analysis described in Section 6.1.2. These seep zones, lines, and points were automated using a procedure similar to that described for vegetation in Section 7.1.1.

\subsection{Data Analysis}

A data analysis scheme was developed to provide a multilayered approach to detecting seeps. The wetlands, irrespective of their origins, were extracted from the automated vegetation map. As described in the Corps' report, Rocky Flats Plant Wetlands Mapping and Resource Study, wetlands may be found on slopes or in stream bottoms. 6

Wetlands found on valley slopes are usually within or near seep areas or complexes. They may be associated with areas of recent or past mass wasting, steep slopes, sharp gradient changes, or sharp vegetation changes. In addition, they can be associated with the contact between the Rocky Flats Alluvium and the upper Arapahoe formation (and up to 40 feet below the contact).

Furthermore, the Corps described the stream bottom wetlands as palustrine, riverine, forested, scrub-shrub, emergent, aquatic bed, or unconsolidated bed wetlands. ${ }^{6}$ They are associated with stream channels, segments,

Table 5. Correlation Between Vegetation Classification Scheme and U.S. Army Corps of Engineers' Wetlands Code

\begin{tabular}{l|l}
\hline New Vegetation Classification & \multicolumn{1}{|c}{ Corps Wetlands Code } \\
\hline Wet Meadow/Marsh Ecotone & PEMA, PEMB, PEMC, PEMF, PABH \\
Short Marsh & PEMA, PEMB, PEMC, PEMF \\
Tall Marsh & PEMA, PEMB, PEMC, PEMF \\
Open Water & L1UBH, PABH, PUBF, PUBH, PUSC \\
Riparian Woodland & PFOA, PFOC \\
Riparian Shrubland & (No Correlation) \\
Riparian Shrubland, Riverine & R4SBC, R4SBG, R4SBJ \\
Riparian Shrubland, Palustrine & PSSA, PSSC \\
\hline
\end{tabular}


and beds and can be found in bank or emergent areas or near ponds and impoundments. In short, these wetlands are associated with stream channels or floodplains having a shallow gradient and no sharp gradient changes.

Seeps were developed as a separable class from wetlands by first extracting the wetlands classes (see Figure 7) from the new "rfveg96" vegetation coverage. The most recent alluvial deposits mapped in the geology coverage provided by RFETS personnel were considered approximately equivalent to floodplains. A floodplains coverage was developed by (a) extracting the Quaternary Post-Piney Creed alluvium polygons from the "geology90" coverage and (b) merging them with a set of polygons developed by using a ten-foot (3.04-meter) buffer around all streams in the "rfhydrography" coverage.

A potential seeps coverage was then developed by erasing all of the floodplain areas in the merged floodplains coverage from the wetlands coverage. These are the wetlands not associated with stream-bottom wetlands (i.e., potential seep areas that are approximately equivalent to the Corps' valley-slope wetlands). Additional analysis included (a) isolating the Rocky Flats Alluvium - upper Arapahoe formation contact, (b) buffering the lower 40 feet, and (c) isolating all slope classes greater than or equal to 20 percent.

Through a union process, MSS- and thermal-infrared-mapped potential seep zones, valley-slope wetlands, the buffered Rocky Flats Alluvium-upper Arapahoe formation contact, and all slope areas greater than or equal to 20 percent were merged into a single GIS polygonal data set. MSS- and thermal-infrared-mapped potential seep lines and linear geomorphic features including scarps, depression edges, and lines of vegetation near springs were merged into a single GIS line data set. MSS- and thermal-infrared-mapped potential seep points and point geomorphic features (i.e., springs) were merged into a single GIS point data set.

Finally, the GIS line and point data sets were analyzed in comparison with the GIS polygonal data set through the ARC/INFO identitification process. This produced a GIS point data set that specified, for every point feature, whether or not each of the four polygonal types intersected. Also produced was a GIS line data set that specified, for every line feature, whether or not each of the four polygonal types intersected. This allows a complete and fully developed overlay analysis of all the feature types associated with seep potential. Note that no line features intersected with point features.

Figure 8 shows the map for seep potential. In this map, seep-potential polygons that map only one of the seep indicators are colored blue; seep-potential polygons that map two of the seep indicators are colored green; seep-potential polygons that map three of the seep indicators are colored yellow; and seep-potential polygons that map all four of the seep indicators are colored red. A higher number of mapped indicators correlates with a higher potential for seeps.

The polygons mapped with three and four seep-potential indicators, which are displayed in yellow and red, have the highest potential for seeps. They are primarily found in the northern half of Area 2, especially along the south flank of South Walnut Creek in the B Ponds area and along the flanks of the headwater tributaries of Rock Creek. Two smaller, isolated areas are found along the north slope of North Walnut Creek just north of the north-central part of Area 1 and along the north flank of the South Interceptor Ditch just south of the south-central part of Area 1.

Figure 8 also shows linear and point indicators for seeps as cyan-colored lines and points, respectively. Locational coincidence of linear or point indicators with any of the polygonal seep-potential indicator classes infer an even greater potential for seeps along a given line or point. 


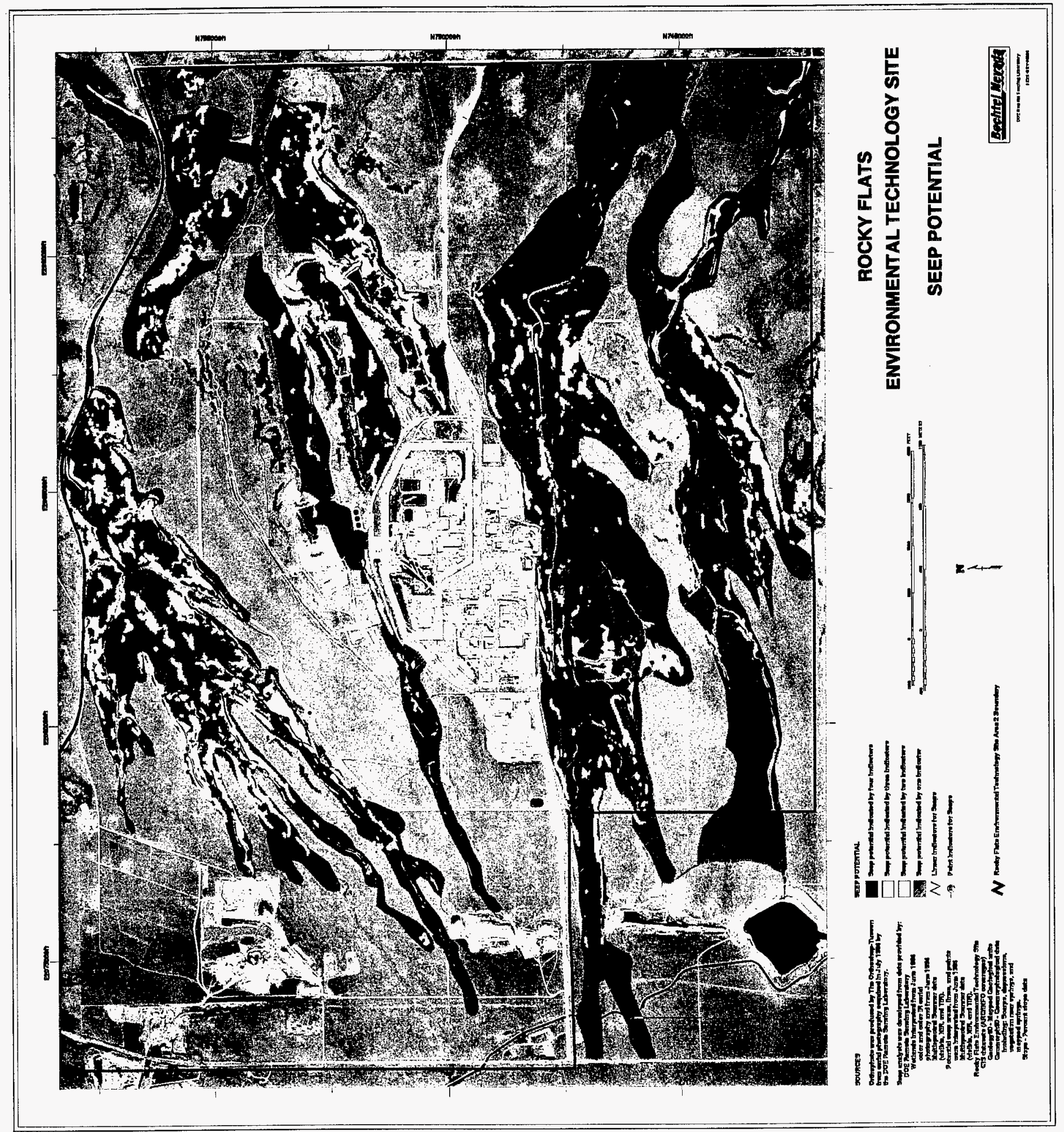




\subsection{Map Production}

The final step was to produce hard-copy outputs. These are shown in Figures 7 (page 19) and 8 (page 22). Draft copies of the vegetation and seeps maps were delivered at a scale of 1:12000. Eastern and western half maps at a scale of 1:6000 for vegetation, wetlands, and seeps were also delivered.

The following final mapping products were delivered under separate cover:

$$
\begin{array}{ll}
\text { SIGIS-RKY-96001 } & \begin{array}{l}
\text { Rocky Flats Environmental Technology Site, Western Half, Vegetation, } \\
\text { 1:6000 Scale. }
\end{array} \\
\text { SIGIS-RKY-96002 } & \begin{array}{l}
\text { Rocky Flats Environmental Technology Site, Eastern Half, Vegetation, } \\
\text { 1:6000 Scale. }
\end{array} \\
\text { SIGIS-RKY-96003 } & \begin{array}{l}
\text { Rocky Flats Environmental Technology Site, Vegetation, 1:12000 Scale. } \\
\text { SIGIS-RKY-96004 }
\end{array} \\
& \begin{array}{l}
\text { Rocky Flats Environmental Technology Site, Western Half, Seep Potential, } \\
1: 6000 \text { Scale. }
\end{array} \\
\text { SIGIS-RKY-96005 } & \begin{array}{l}
\text { Rocky Flats Environmental Technology Site, Eastern Half, Seep Potential, } \\
\text { 1:6000 Scale. }
\end{array} \\
\text { SIGIS-RKY-96006 } & \text { Rocky Flats Environmental Technology Site, Seep Potential, 1:12000 Scale. } \\
\text { SIGIS-RKY-96007 } & \text { Rocky Flats Environmental Technology Site, Site Map, 1:12000 Scale. }
\end{array}
$$

The 1:6000-scale maps overlay the eastern and western halves of the orthophoto sheets.

\subsection{SUMMARY AND CONCLUSIONS}

The RSL conducted an airborne MSS survey of the RFETS in Golden, Colorado. The survey was conducted in June 1994 using a Daedalus AADS1268 MSS and coincident aerial color and CIR photography. The multispectral survey was initiated as part of an attempt to improve the existing vegetation classification map, to identify seeps and springs, and to generate ARC/INFO - compatible coverages of the vegetation and wetlands for the entire site including the buffer zone.

The MSS imagery and coincident aerial photography were analyzed for the detection, identification, and mapping of vegetation and wetlands. The MSS data were processed digitally while the color and CIR photography were manually photointerpreted to define the vegetation, wetlands, and land cover. Several standard image-enhancement techniques were applied to the MSS data to assist image interpretation. A photointerpretation of the aerial photography was performed to identify and map vegetation (including wetlands) for the RFETS (including the buffer zone). Digitally enhanced MSS data and CIR photography were used as corroborative data during the photointerpretation. ARC/INFO GIS data sets were produced that contained the vegetation and wetlands coverages.

Potential seeps were identified through a rigorous analysis of MSS data including TIR and spatially analyzed data in conjunction with the mapped wetlands from the new vegetation map, as well as hydrography, geology, geomorphology, and slope data sets provided by RFETS personnel. ARC/INFO GIS data layers were produced that mapped polygonal, linear, and point sites especially suitable for finding seeps.

A set of vegetation and potential seep maps were produced at scales of 1:6000 and 1:12000. Wetlands were mapped as a subset of vegetation in the vegetation maps. A site map was also produced at a scale of 1:12000. Digital vegetation and potential-seep data sets with metadata have also been provided. 


\section{REFERENCES}

1. Best, R.G.; S.B. Brewster, Jr.; E.L. Doak; and J.E. Shines. A Multispectral Scanner Survey of the United States Department of Energy's Rocky Flats Plant, Golden, CO. Report No. MRSD 8902, EG\&G Energy Measurements, Las Vegas, NV; 1989.

2. Swain, P. and S. Davis. Remote Sensing: The Quantitative Approach. McGraw Hill, 1978; pp 164-174.

3. Lillesand. T.M. and R.W. Kiefer. Remote Sensing and Image Interpretation. John Wiley and Sons; p 119.

4. Cowardin, L.M:; V. Carter; F.C. Golet; and E.T. LaRoe. Classification of Wetlands and Deepwater Habitats of the United States. Report No. FWS/OBS-79/31, U.S. Fish and Wildlife Service, $1979 ; \mathrm{p} 131$.

5. Bates, R.L. and J.A. Jackson, editors. Glossary of Geology. American Geological Institute, 1980; p 749.

6. U.S. Army Corps of Engineers, Rocky Flats Plant Wetlands Mapping and Resource Study. Army Corps of Engineers, Omaha District; p 55.

7. Schowengerdt, R.A. Techniques for Image Processing and Classification in Remote Sensing. Academic Press, 1983; p 157.

8. Crist, E.P. Application of the Tasseled Cap Concept to Simulated Thematic Mapper Data, Photogrammetric Engineering and Remote Sensing. 50(3):343-352; 1984.

9. EG\&G Rocky Flats, "Vegetation at Rocky Flats Plant," [Vegetation Classification Scheme]. EBASCO, 1992. 
DOE/DP

L. E. Gordon-Hagerty

DOE/NV

K.D. Lachman

Public Reading Room

TIRC

DOE/RF

N. Castaéda
(1))

RMRS (continued)

B. Todeschini

J. Nelson
(1)

\section{BN}

R.G. Best LVAO (1)

(1) S. B. Brewster, Jr. LVAO (1)

(1)

(1)

D.W. Brickey

C. E. Ezra

P. P. Guss

R. E. Kelley

LVAO

(1)

J. T. Mitchell

WAMO

(1)

S. L. Ross

LVAO

(1)

LVAO

(1)

L. G. Sasso

LVAO

(1)

J. E. Shines

LVAO

J. Tinney

LVAO

(1)

(1)

(1)

LVAO

\section{LIBRARIES}

RSL

\section{RMRS}

(1)

(1)

OSTI

(2)

\footnotetext{
A MULTISPECTRAL SCANNER SURVEY OF

THE ROCKY FLATS ENVIRONMENTAL

TECHNOLOGY SITE

AND SURROUNDING AREA

GOLDEN, COLORADO

DOE/NV/11718-039

DATE OF SURVEY: JUNE 1994

DATE OF REPORT: APRIL 1997
} 


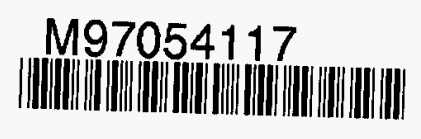

Report Number (14)DOE/NV/117/8- 039

Publ. Date (11) $\frac{19970 \psi}{D O E / D P, X F}$

Sponsor Code (18) $\frac{D O E / D P, X F}{U C-7 O 2, D O E / E R}$ 